\title{
Climbing Fiber Activation of EAAT4 Transporters and Kainate Receptors in Cerebellar Purkinje Cells
}

\author{
Yanhua H. Huang, ${ }^{1}$ Margaret Dykes-Hoberg, ${ }^{2}$ Kohichi Tanaka, ${ }^{3}$ Jeffrey D. Rothstein, ${ }^{2}$ and Dwight E. Bergles ${ }^{1}$ \\ Departments of ${ }^{1}$ Neuroscience and ${ }^{2}$ Neurology, Johns Hopkins University, Baltimore, Maryland 21205, and ${ }^{3}$ Laboratory of Molecular Neuroscience, School \\ of Biomedical Science and Medical Research Institute, Tokyo Medical and Dental University, Tokyo, Japan 113-8510
}

\begin{abstract}
Cerebellar Purkinje cells (PCs) express two glutamate transporters, EAAC1 (EAAT3) and EAAT4; however, their relative contribution to the uptake of glutamate at synapses is not known. We found that glutamate transporter currents recorded at climbing fiber (CF)-PC synapses are absent in mice lacking EAAT4 but unchanged in mice lacking EAAC1, indicating that EAAT4 is preferentially involved in clearing glutamate from CF synapses. However, comparison of CF synaptic currents between wild-type and transporter knock-out mice revealed that ionotropic glutamate receptors are responsible for $>40 \%$ of the current previously attributed to transporters, indicating that PCs remove $<10 \%$ of the glutamate released by the CF. The receptors responsible for the nontransporter component accounted for $5 \%$ of the CF EPSC, had a slower time course and lower occupancy than AMPA receptors at CF synapses, and exhibited pharmacological properties consistent with kainate receptors. In GluR5 knock-out mice, this current was dramatically reduced, indicating that CF excitation of PCs involves two distinct classes of ionotropic glutamate receptors, AMPA receptors and GluR5-containing kainate receptors.
\end{abstract}

Key words: cerebellum; EAAT4; EAAC1; Purkinje neuron; GluR5; kainate receptor; EPSC; glutamate transporter

\section{Introduction}

Glutamate is cleared from excitatory synapses by diffusion, dilution in the extracellular space, and uptake by transporters. Transporter activity is essential for maintaining a low ambient level of glutamate (Rothstein et al., 1996; Tanaka et al., 1997), and, at many synapses, this activity restricts the size and duration of EPSCs (Barbour et al., 1994; Tong and Jahr, 1994; Otis et al., 1996; Brasnjo and Otis, 2001; Diamond, 2001; Arnth-Jensen et al., 2002). Five different glutamate transporters are expressed in the mammalian CNS; GLAST (EAAT1) and GLT-1 (EAAT2) are found predominantly in glial cells, and EAAC1 (EAAT3) and EAAT4 are expressed by neurons (Danbolt, 2001). Although considerable information is available about the localization and density of these transporters (Rothstein et al., 1994; Lehre and Danbolt, 1998), their relative contribution to the uptake of synaptic glutamate is poorly understood, because antagonists selective for each transporter have not yet been developed.

Our knowledge about neuronal glutamate uptake is primarily based on studies of climbing fiber (CF)-Purkinje cell (PC) synapses in the cerebellum, the only CNS synapses in which both anion and stoichiometric (coupled) currents associated with glutamate transport have been resolved in the postsynaptic neuron.

Received Oct. 1, 2003; revised Nov. 3, 2003; accepted Nov. 3, 2003.

This work was supported by National Institutes of Health Grants NS041680 (J.D.R.) and NS44261 (D.E.B.), the Packard Center for ALS Research at Johns Hopkins University (D.E.B.), and the Sloan Foundation (D.E.B.). We thank Anis Contractor and Stephen Heinemann for providing GluR5 knock-out mice, Eli Lilly for providing LY 382884 Marlin Dehoff and Naoko Nishiyama for assistance with genotyping, and David Linden and Craig Jahr for helpful discussions.

Correspondence should be addressed to Dwight Bergles, Department of Neuroscience, Johns Hopkins University, 725 North Wolfe Street, WBSB 813, Baltimore, MD 21205. E-mail: dbergles@jhmi.edu.

DOI:10.1523/JNEUROSCI.4473-03.2004

Copyright $\odot 2004$ Society for Neuroscience $\quad$ 0270-6474/04/240103-09\$15.00/0
In addition to EAAC1, PCs express EAAT4, a transporter that exhibits a 10-fold higher affinity for glutamate than other glutamate transporters (Fairman et al., 1995). Measurements of the charge transferred during CF synaptic transporter currents have been used to estimate the amount of glutamate taken up by PCs (Otis et al., 1997; Auger and Attwell, 2000). An initial study concluded that at least $22 \%$ of the glutamate released at CF synapses was removed by PCs, or more if EAAC1 also contributed to uptake currents (Otis et al., 1997). Although this estimate was based on measurements of transporter-associated anion currents, a recent study described a CF-induced synaptic current that was attributed to the movement of charge directly coupled to glutamate transport (Auger and Attwell, 2000). This study concluded that PCs remove the majority of glutamate (56-230\%) released at CF synapses. However, this putative transporter current was only partially inhibited by DL-threo- $\beta$-benzyloxyaspartic acid (TBOA) (Auger and Attwell, 2000), an antagonist that blocks all glutamate transporters (Shimamoto et al., 1998; Shigeri et al., 2001), raising questions about the accuracy of these estimates.

To determine both the contribution of EAAC1 and EAAT4 to uptake of synaptic glutamate and the reason for the partial sensitivity of the putative synaptic transporter current to TBOA, we recorded $\mathrm{CF}$ responses in cerebellar slices prepared from mice deficient in neuronal transporters. We found that EAAT4 is responsible for the glutamate transporter currents recorded at CF-PC synapses. In addition, our results indicate that previous studies have overestimated the amount of glutamate captured by PCs, because non-AMPA glutamate receptors account for $>40 \%$ of the putative transporter current. These non-AMPA receptors at CF synapses exhibited pharmacological and kinetic features characteristic of GluR5-containing kainate receptors and were responsible for $\sim 5 \%$ of the CF EPSC. 


\section{Materials and Methods}

Generation of mice deficient in neuronal transporters. EAAC1 ${ }^{-1-}$ and GluR5 ${ }^{-1-}$ mice were generated as described previously (Peghini et al., 1997; Contractor et al., 2000). For targeted disruption of the EAAT4 gene, the exon 7 , including the sixth transmembrane segment, was replaced by a neomycin-resistant gene. The linearized targeting vector was electroporated into embryonic day 14 embryonic stem (ES) cells, and one ES cell line with a single targeted allele was used for the generation of $E_{A A T 4^{-1-}}$ mice (H. Maeno, K. Watase, K. Wada, K. Tanaka, unpublished observations). To generate $E A A C 1^{-1-} \times E A A T 4^{-1-}$ mice as well as other genotypes with comparable backgrounds, hybrids of the two lines (genotype, $E A A C 1^{+/-} \times E A A T 4^{+/-}$) were used to generate two sets of mice. The first set had one mutant allele $\left(E A A C 1^{-1-}\right.$ or $\left.E A A T 4^{-1-}\right)$ and one heterozygous allele $\left(E A A C 1^{+/-}\right.$or $\left.E A A T 4^{+/-}\right)$, which were then used to generate double mutants $\left(E A A C 1^{-1-} \times E A A T 4^{-1-}\right)$ or single mutants $\left(E A A C 1^{-1-}\right.$ or $\left.E A A T 4^{-1-}\right)$. The second set had one wild-type allele $\left(E A A C 1^{+/+}\right.$or $\left.E A A T 4^{+/+}\right)$and one heterozygous allele $\left(E A A C 1^{+/-}\right.$or $\left.E A A T 4^{+/-}\right)$, which were then used to generate wild-type mice $\left(E A A C 1^{+/+} \times E_{A A T 4^{+/+}}\right)$as well as single mutant mice. All comparisons between different genotypes (see Figs. 1, 2, 3) were performed using mice generated in this manner. Additional double mutants were obtained from the subsequent mating of double mutants (see Figs. 4, 5). The genotypes of all experimental animals were confirmed by PCR.

Immunoblotting and immunostaining. Mice were killed using approved animal welfare protocols and perfused by cardiac puncture with $4 \%$ paraformaldehyde-PBS. Brains were removed, and tissue blocks were cryopreserved for sectioning. For immunoblotting, tissue was rapidly frozen on dry ice and stored at $-70^{\circ} \mathrm{C}$ until assayed. Samples from postnatal day 18 (P18)-P21 cerebellum were homogenized with a Brinkmann Polytron (Westbury, NY) or by sonication in $20 \mathrm{~mm}$ Tris- $\mathrm{HCl}, \mathrm{pH}$ 7.4, containing $10 \%$ sucrose and protease inhibitor mixture (Roche Diagnostics, Hertforshire, UK). These cerebellar extracts were subjected to 7.5\% SDS-PAGE and transferred to nitrocellulose membrane [Hybond enhanced chemiluminescence (ECL)] by electroblotting (30 V; $60 \mathrm{~min}$ ). Western analysis was performed as described previously (Rothstein et al., 1994). Blots were probed with affinity-purified polyclonal antibody specific for EAAC1 (carboxy terminus-directed antibody at $0.6 \mu \mathrm{g} / \mathrm{ml}$ ), EAAT4 (carboxyterminus-directed antibody at $0.4 \mu \mathrm{g} / \mathrm{ml}$ ), or actin (1: 500; Sigma, St. Louis, MO) using horseradish peroxidase-conjugated donkey anti-rabbit Ig (Amersham Biosciences, Arlington Heights, IL) (diluted 1:5000 in blocking solution) as secondary antibody. Immunoreactive proteins were visualized by ECL. Immunoblots were run at least two times.

For immunohistochemistry, sections $(50 \mu \mathrm{m})$ of cryopreserved mouse brain (P19-P20) were cut on a sliding microtome and then transferred to cold TBS $(0.05 \mathrm{~m}$ Tris, $0.15 \mathrm{M} \mathrm{NaCl}, \mathrm{pH}$ 7.4). Sections were pretreated with $3 \%$ hydrogen peroxide $/ 0.1 \%$ Triton X-100 in TBS, rinsed and blocked $\left(1 \mathrm{hr} ; 4^{\circ} \mathrm{C}\right)$ in TBS containing $5 \%$ normal goat serum, and $0.1 \%$ Triton X-100. Sections were incubated $\left(48-72 \mathrm{hr} ; 4^{\circ} \mathrm{C}\right)$ in one of the affinity-purified antipeptide antibodies (EAAC1, $0.06 \mu \mathrm{g} / \mathrm{ml}$; EAAT4, $0.4 \mu \mathrm{g} / \mathrm{ml}$ ) or anticalbindin (1:2000; Sigma) antibody in TBS containing $2 \%$ normal goat serum and $0.1 \%$ Triton X-100. The monospecificity of the affinity-purified antibodies had been confirmed previously using preadsorption overnight with excess $(5 \mu \mathrm{M})$ corresponding synthetic oligopeptide, or primary antisera was omitted. After the primary antibody incubation, sections were incubated $\left(1 \mathrm{hr} ; 4^{\circ} \mathrm{C}\right)$ with biotinylated secondary antibody (Vector Laboratories, Burlingame, CA) to rabbit IgG diluted 1:400 (for all glutamate transporter antibodies) in TBS containing $2 \%$ normal goat serum and then rinsed and incubated $\left(1 \mathrm{hr} ; 4^{\circ} \mathrm{C}\right)$ in $\mathrm{ABC}$ reagent 1:200 in TBS (Elite kit; Vector Laboratories), followed by $0.05 \%$ diaminobenzidine $/ 0.01 \%$ hydrogen peroxide in TBS. Tissue staining was performed on two animals from each group (wild-type, $E A A C 1^{-1-}$, $E A A T 4^{-1-}$, and $E A A C 1^{-1-} \times E A A T 4^{-1-}$ ).

Acute slice preparation. Parasagittal cerebellar slices were prepared from 15- to 19-d-old mice and 13- to 15 -d-old rats $(250 \mu \mathrm{m})$ on a vibratome (VT1000S; Leica, Nussloch, Germany) in ice-cold artificial CSF (ACSF) containing (in $\mathrm{mm}$ ): $119 \mathrm{NaCl}, 2.5 \mathrm{KCl}, 2.5 \mathrm{CaCl}_{2}, 1.3$ $\mathrm{MgCl}_{2}, 1 \mathrm{NaH}_{2} \mathrm{PO}_{4}, 26.2 \mathrm{NaHCO}_{3}$, and 11 glucose saturated with $95 \%$
$\mathrm{O}_{2} / 5 \% \mathrm{CO}_{2}$. Slices were incubated in ACSF at $37^{\circ} \mathrm{C}$ for $30 \mathrm{~min}$ and then allowed to recover for at least $30 \mathrm{~min}$ at room temperature before experimentation.

Electrophysiological recordings. PCs were visualized through a $40 \times$ water immersion objective using infrared light, differential interference contrast optics, and a CCD camera (XC-73; Sony, Tokyo, Japan). Wholecell recordings were made under visual control with an internal solution consisting of (in mM): $105 \mathrm{CsA}$ [A represents $\mathrm{NO}_{3}{ }^{-}$or $\mathrm{CH}_{3} \mathrm{O}_{3} \mathrm{~S}^{-}$ (MeS)], 20 TEA-Cl, 10 EGTA, 20 HEPES, 2 Mg-ATP, 0.2 Na-GTP, 1 $N$-ethyl bromide quaternary salt, $\mathrm{pH}$ 7.3. CFs were stimulated with a $\theta$ glass pipette filled with ACSF. A constant-current isolated stimulator (DS3; Digitimer, Hertfordshire, UK) was used to supply a $100 \mu$ sec pulse of 2-30 $\mu \mathrm{A}$. Pipette position was adjusted to minimize the stimulus intensity required to generate an all-or-none CF-evoked response. Subthreshold stimulation did not induce EPSCs, indicating that there was no contamination by parallel fiber synapses. Synaptic currents were recorded with a MultiClamp 700A amplifier (Axon Instruments, Foster City, CA), filtered at $2-3 \mathrm{kHz}$, amplified $20 \times(440$; Brownlee, San Jose, $\mathrm{CA})$, and then digitized at $10 \mathrm{kHz}$ with a Digidata $1322 \mathrm{~A}$ analog-todigital converter (Axon Instruments). Data were analyzed off-line using pClamp (Axon Instruments) and Origin (Microcal Software, Northampton, MA) software. All recordings were made at room temperature unless otherwise noted.

Data analysis. By optimizing the position of the stimulation pipette, it was possible to obtain CF EPSCs and residual EPSCs (rEPSCs) that were well separated from the stimulus artifact. Although subtraction of the artifact was not performed, in most traces, the artifact has been blanked for clarity. The rise time of synaptic currents was measured from 10 to $90 \%$ of peak amplitude. The decay kinetics of CF rEPSCs and EPSCs recorded in 1-(4-aminophenyl)-3-methylcarbamyl-4-methyl-7,8methylenedioxy-3,4-dihydro-5H-2,3-benzodiazepine (GYKI 53655) was calculated by fitting a single exponential $\left(y=y_{0}+A_{1} e^{-(x-x 0) / t 1}\right)$ to the decay from $\sim 10 \%$ below the peak. The decay of CF EPSCs under control conditions could not be fitted with a single exponential. Therefore, the half-decay time was measured to provide an indication of the decay time course. Reversal potentials for CF EPSCs and rEPSCs were measured by performing a linear regression fit of the $I-V$ data from each individual experiment. The estimated reversal potentials have not been corrected for the junction potential. All results are presented as mean \pm SEM.

\section{Results}

\section{CF synaptic transporter currents from wild-type mice}

To determine the relative contribution of EAAC1 and EAAT4 to the PC glutamate transporter current, we compared CF synaptic currents recorded from wild-type mice with those recorded from mice lacking EAAC1 (Peghini et al., 1997), EAAT4, or both EAAC1 and EAAT4 transporters. We confirmed that transporter expression was disrupted in $E A A C 1^{-1-}, E A A T 4^{-1-}$, and $E A A C 1^{-1-} \times E A A T 4^{-1-}$ mice by PCR (data not shown), Western blot analysis (Fig. $1 A$ ), and immunocytochemistry (Fig. $1 B$ ). Despite the absence of neuronal glutamate transporters, these animals survived into adulthood (Peghini et al., 1997), did not exhibit obvious motor discoordination, and had grossly normal cerebellar architecture (Fig. $1 B$ ). In slices prepared from wildtype mice, CF stimulation elicited large amplitude all-or-none synaptic currents in PCs similar to those observed in rats (Perkel et al., 1990) (Fig. 2A). This CF EPSC was reduced to $<1 \%$ of its original amplitude during application of antagonists of AMPA receptors [2,3-Dioxo-6-nitro-1,2,3,4-tetrahydrobenzo[f] quinoxaline-7sulfonamide (NBQX), $25 \mu \mathrm{M}$; 1-(4-Aminophenyl)-4-methyl-7,8methylenedioxy-5H-2,3-benzodiazepine hydrochloride (GYKI 52466), $25 \mu \mathrm{M}$ ], NMDA receptors [(RS)-3-(2-Carboxypiperazin4-yl)-propyl-1-phosphonic acid (RS-CPP), $10 \mu \mathrm{M}$ ] and $\mathrm{GABA}_{\mathrm{A}}$ receptors (SR-95531, $5 \mu \mathrm{M}$; bicuculline, $20 \mu \mathrm{M}$ ). The residual synaptic current (rEPSC) recorded in the presence of these antagonists was $-23.0 \pm 1.5 \mathrm{pA}(n=9)(\mathrm{Vm}=-65 \mathrm{mV})$ when 


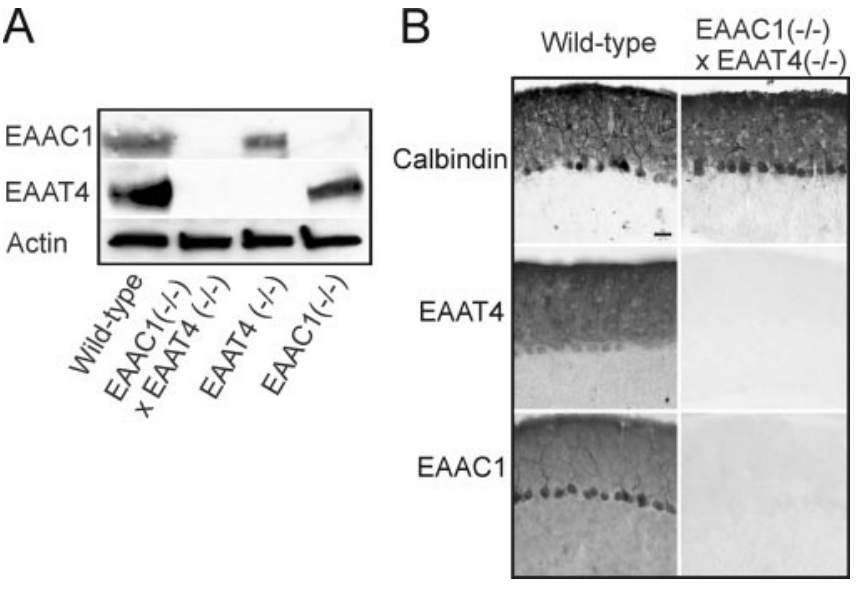

Figure 1. Generation of mice deficient in neuronal glutamate transporters. $A$, Western blot of cerebellar tissue from wild-type and transporter knock-out mice using anti-EAAC1 and antiEAAT4 antibodies. EAAC1 protein was not detected in tissue from EAAC1 ${ }^{-1-}$ and $E A A C 1^{-1-} \times$ EAAT4 ${ }^{-1-}$ mice, and EAAT4 protein was not detected in EAAT4 ${ }^{-1-}$ and EAAC $1^{-1-} \times E A A T 4^{-1-}$ mice. Immunoblotting with antiactin antibodies demonstrates that a comparable amount of protein was loaded into each lane. $B$, Immunostaining of cerebellar slices from wild-type and transporter knock-out mice. EAAT4 and EAAC1 immunoreactivity was absent in EAAC1 ${ }^{-1-} \times E A A T 4^{-1-}$ mice. Immunostaining with anticalbindin antibodies shows that the morphology of Purkinje cells was normal in $E A A C 1^{-1-} \times E_{A A T 4}{ }^{-1-}$ mice. Scale bar, $50 \mu \mathrm{m}$.

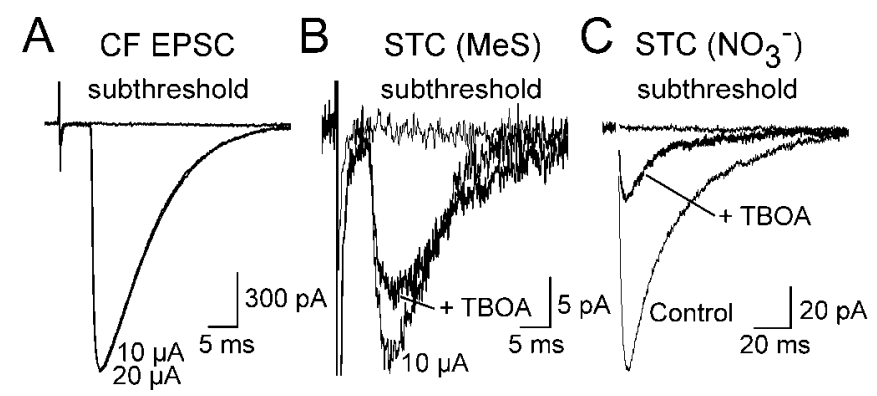

Figure 2. Glutamate transporter activation at CF-PC synapses. $A, A$ CF EPSC recorded in a PC from a wild-type mouse (P16). The CF response exhibited a sharp stimulation threshold of 10 $\mu \mathrm{A}$ and all-or-none behavior. The holding potential was $-10 \mathrm{mV}$, and the internal solution was CsMeS. B, The CF EPSC recorded from the cell in $A$ after application of $25 \mu \mathrm{M}$ NBQX, $25 \mu \mathrm{M}$ GYKI 52466, $10 \mu \mathrm{m}$ RS-CPP, $5 \mu \mathrm{m}$ SR-95531, and $20 \mu \mathrm{m}$ bicuculline to block AMPA, NMDA, and $\mathrm{GABA}_{A}$ receptors. This residual current was clearly separated from the stimulus artifact and exhibited the same threshold as the CF EPSC. This response was inhibited by TBOA (200 $\mu \mathrm{m})$ (dark trace). The holding potential was $-65 \mathrm{mV}$. C, A CF EPSC recorded with a $\mathrm{CsNO}_{3}$ internal solution in the same antagonists as $B$. This CF response was larger, had slower kinetics, and was inhibited to a greater extent by TBOA (dark trace). The holding potential was $-65 \mathrm{mV}$.

recordings were made with an internal solution that contained $\mathrm{MeS}$ as the primary internal anion, which does not permeate the glutamate transporter anion channel (Bergles et al., 2002), and exhibited the same threshold and all-or-none behavior as the CF EPSC (Fig. 2B). This current had rapid rise and decay kinetics (rise time, $2.3 \pm 0.2 \mathrm{msec}$; decay tau, $9.1 \pm 1.2 \mathrm{msec} ; n=9$ ) (Fig. $2 B)$, similar to currents recorded from rat (Auger and Attwell, $2000)$, and was inhibited by $38.2 \pm 2.9 \%(n=4)$ by TBOA $(200$ $\mu \mathrm{M}$ ), a selective antagonist of glutamate transporters (Shimamoto et al., 1998; Shigeri et al., 2001). These results indicate that a stoichiometric or coupled transport current reflecting the movement of charge directly associated with glutamate uptake mediates a portion of the CF rEPSC. When recordings were made with $\mathrm{NO}_{3}{ }^{-}$as the primary internal anion, which is highly permeant through glutamate transporters (Wadiche et al., 1995), this residual current was larger (amplitude, $-76.4 \pm 15.9 \mathrm{pA} ; p<$
0.05 ) and decayed more slowly (rise time, $2.8 \pm 0.4 \mathrm{msec}, p=$ 0.27; decay tau, $37.2 \pm 2.3 \mathrm{msec}, n=4, p<0.001$ ) (Fig. $2 C$ ), similar to that observed for transporter currents in outside-out patches (Auger and Attwell, 2000; Bergles et al., 2002), and was inhibited to a greater extent by TBOA (inhibition, $73.2 \pm 2.8 \%$; $n=4$; $p<0.001$ ) (Fig. $2 C$ ). These data indicate that both stoichiometric (coupled) and anion (uncoupled) currents associated with glutamate transport can be recorded in PCs from wild-type mice in response to CF stimulation. We used these two features of glutamate transporters, the potentiation by permeant anions and the inhibition by TBOA, to address whether glutamate transporter currents were disrupted in mice lacking EAAC1, EAAT4, or both EAAC1 and EAAT4.

\section{EAAT4 is responsible for the CF glutamate transporter current}

As shown in Figure $3 A$, both the amplitude and decay time of $\mathrm{CF}$ rEPSCs from EAAC1 ${ }^{-1-}$ mice were increased when $\mathrm{NO}_{3}{ }^{-}$rather than $\mathrm{MeS}$ was used as the primary internal anion, similar to responses from wild-type mice (Fig. 2). In contrast, there was no significant difference in the amplitude or decay time of $\mathrm{CF}$ rEPSCs from EAAT4 $4^{-1-}$ or EAAC1 $1^{-1-} \times E A A T 4^{-1-}$ mice when $\mathrm{NO}_{3}{ }^{-}$rather than $\mathrm{MeS}$ was used as the primary internal anion (Fig. $3 A, B$ ). Furthermore, the amount of inhibition of $\mathrm{CF}$ rEPSCs by TBOA was reduced in EAAT4 ${ }^{-1-}$ mice, and there was no significant difference in TBOA inhibition between $E A A T 4^{-1-}$ and $E A A C 1^{-1-} \times E A A T 4^{-1-}$ mice (Fig. $3 A, C$ ). These data indicate that EAAT4 is responsible for the anion-potentiated CF glutamate transporter current. However, because EAAT4 exhibits a much higher anion permeability than EAAC1 (Fairman et al., 1995; Wadiche et al., 1995), it is possible that EAAT4 could be the predominant transporter when $\mathrm{NO}_{3}{ }^{-}$is the main internal anion but a minor component when permeant anions are not present. If EAAC1 contributes to the coupled transporter current (recorded with $\mathrm{MeS}$ ), there should be a difference in the amount of inhibition by TBOA between EAAT4 ${ }^{-1-}$ and $E A A C 1^{-1-} \times E A A T 4^{-1-}$ mice. However, there was no significant difference in TBOA inhibition of CF rEPSCs between these animals (Fig. 3C). Furthermore, under these conditions, CF rEPSCs from EAAT4 ${ }^{-1-}$ mice were inhibited significantly less than CF rEPSCs from wild-type mice $(p<0.05)$. These data indicate that both stoichiometric and anion transporter currents recorded at CF synapses are mediated by EAAT4 rather than EAAC1.

The presence of a small TBOA-sensitive current in mice that lack both EAAC1 and EAAT4 suggested that TBOA may have secondary effects, or that PCs may express an additional glutamate transporter. Previous studies have shown that blocking glutamate transporters with TBOA causes glutamate to accumulate in the extracellular space (Jabaudon et al., 1999; Arnth-Jensen et al., 2002), which could inhibit release by activating presynaptic metabotropic glutamate receptors on CF terminals (Tamaru et al., 2001; Harrison and Jahr, 2003). Consistent with this possibility, TBOA increased the paired-pulse ratio (PPR) of CF rEPSCs by $37.9 \pm 8.3 \%(n=5 ; p<0.01)$ in $E A A C 1^{-1-} \times E A A T 4^{-1-}$ mice (Fig. $4 A$ ), suggesting that TBOA decreased the release probability of CF terminals. Furthermore, both the decrease in amplitude and the increase in PPR were blocked when TBOA was applied in the presence of the group I/II metabotropic glutamate receptor antagonist (RS)-a-methyl-4-carboxyphenylglycine (MCPG; $1 \mathrm{~mm}$; amplitude decreased by $0.6 \pm 4.0 \%, n=7, p=$ 0.62 ; PPR increased by $1.5 \pm 3.7 \%, n=5, p=0.44$ ) (Fig. $4 B$ ). These results indicate that the TBOA-induced decrease in amplitude of the CF response in $E A A C 1^{-1-} \times E A A T 4^{-1-}$ mice was 
attributable to a reduction in glutamate release from CF terminals, rather than an inhibition of latent glutamate transporters in PCs. In the absence of neuronal transporters, TBOA application presumably increases extracellular glutamate by inhibiting glutamate uptake into surrounding Bergmann glial cells (Rothstein et al., 1994; Bergles et al., 1997).

We estimated the proportion of the CF rEPSC mediated by glutamate transporters by measuring the amplitude of the TBOA-sensitive current in the presence of $\mathrm{MCPG}$. In recordings with $\mathrm{MeS}$ as the primary internal anion, EAAT4 transporters were responsible for $57.2 \pm 3.9 \%(n=4)$ of the CF rEPSC in rats and $36.4 \pm 5.5 \%$ $(n=4)$ of the CF rEPSC in wild-type mice (Fig. 4C). To address whether these transporters capture more glutamate at physiological temperatures, we recorded $\mathrm{CF}$ rEPSCs at $34-36^{\circ} \mathrm{C}$. The TBOA-sensitive charge movement at this temperature was $94 \pm 13 \%(n=4 ; p=0.493)$ of that observed at room temperature, suggesting that EAAT4 captures approximately the same amount of glutamate at near physiological temperatures.

\section{Non-AMPA glutamate receptors at CF synapses}

As shown above (Fig. 2), and previously (Auger and Attwell, 2000), the CF rEPSC recorded from wild-type animals in the presence of $25 \mu \mathrm{M}$ NBQX was only partially inhibited by TBOA $(200 \mu \mathrm{M})$. Because TBOA blocks all high-affinity $\mathrm{Na}^{+}{ }_{-}$ dependent glutamate transporters with a $K_{m}$ of $3-50 \mu \mathrm{M}\left(K_{i}\right.$ at EAAT4 $\left.=4.4 \mu \mathrm{M}\right)$ (Shimamoto et al., 2000; Shigeri et al., 2001), these data suggest that a significant portion of the CF rEPSC is not mediated by glutamate transporters. Consistent with this hypothesis, a CF synaptic current remained in $E A A C 1^{-1-} \times E A A T 4^{-1-}$ mice in the presence of $25 \mu \mathrm{M}$ NBQX and $25 \mu \mathrm{M}$ GYKI 52466 (Fig. 3A). To determine the properties of the receptors responsible for this current, we examined CF rEPSCs in $E A A C 1^{-1-} \times E A A T 4^{-1-}$ mice, avoiding contamination of this current by glutamate transporters. The reversal potential of the rEPSC was $8.6 \pm 2.4 \mathrm{mV}(n=6)$ (Fig. $5 A, B$ ), similar to that of the CF EPSC (reversal potential, $8.2 \pm 1.0 \mathrm{mV} ; n=5$; $p=0.46$ ), suggesting that this current also is mediated by a nonselective cation channel. Although it is unlikely that the $\mathrm{CF}$ rEPSC is mediated by unblocked AMPA receptors given the slow dissociation rate of NBQX (Diamond and Jahr, 1997) and the noncompetitive nature of antagonism by GYKI 52466, we tested this possibility
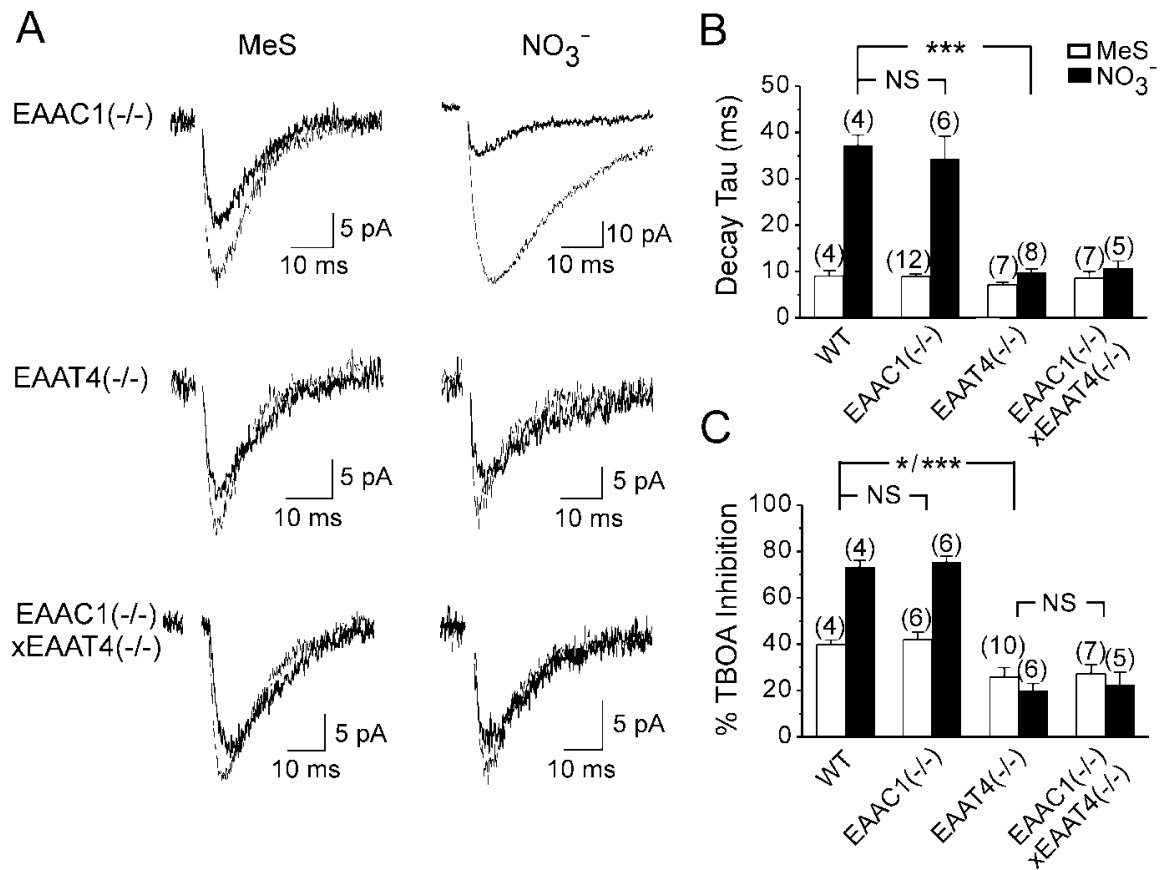

Figure 3. Glutamate transporter currents are absent in mice lacking EAAT4. A, CF synaptic currents recorded from mice lacking EAAC1, EAAT4, or both EAAC1 and EAAT4 glutamate transporters. Recordings were made with either MeS (left traces) or $\mathrm{NO}_{3}{ }^{-}$ (right traces) as the primary internal anion. The dark traces show the response after application of $200 \mu \mathrm{M}$ TBOA. B, Summary of the decay tau of CF synaptic currents from wild-type and transporter knock-out mice recorded with either MeS (open bars) or $\mathrm{NO}_{3}{ }^{-}$(closed bars) as the primary internal anion. CF synaptic currents from mice lacking EAAT4 did not exhibit anion-induced slowing, whereas CF synaptic currents from mice lacking EAAC1 were indistinguishable from wild type. The numbers in parentheses indicate the number of experiments performed. Comparisons refer to recordings made with $\mathrm{NO}_{3}{ }^{-}$. $\mathrm{C}$, Summary of the percentage of inhibition of CF synaptic currents by $200 \mu \mathrm{M}$ TBOA. TBOA inhibition was reduced in mice lacking EAAT4 but unaffected in mice lacking EAAC1. ${ }^{*}$, MeS groups; ${ }^{* * *}, \mathrm{NO}_{3}{ }^{-}$groups. All currents were recorded in the presence of $25 \mu \mathrm{M} \mathrm{NBQX}$, $20 \mu \mathrm{M}$ GYKI 52466, $10 \mu \mathrm{M}$ RS-CPP, $5 \mu \mathrm{m}$ SR-95531, and $20 \mu \mathrm{m}$ bicuculline at a holding potential of $-65 \mathrm{mV} .{ }^{*} p<0.05$; ${ }^{* * *} p<$ $0.001 ;$ NS, not significant.
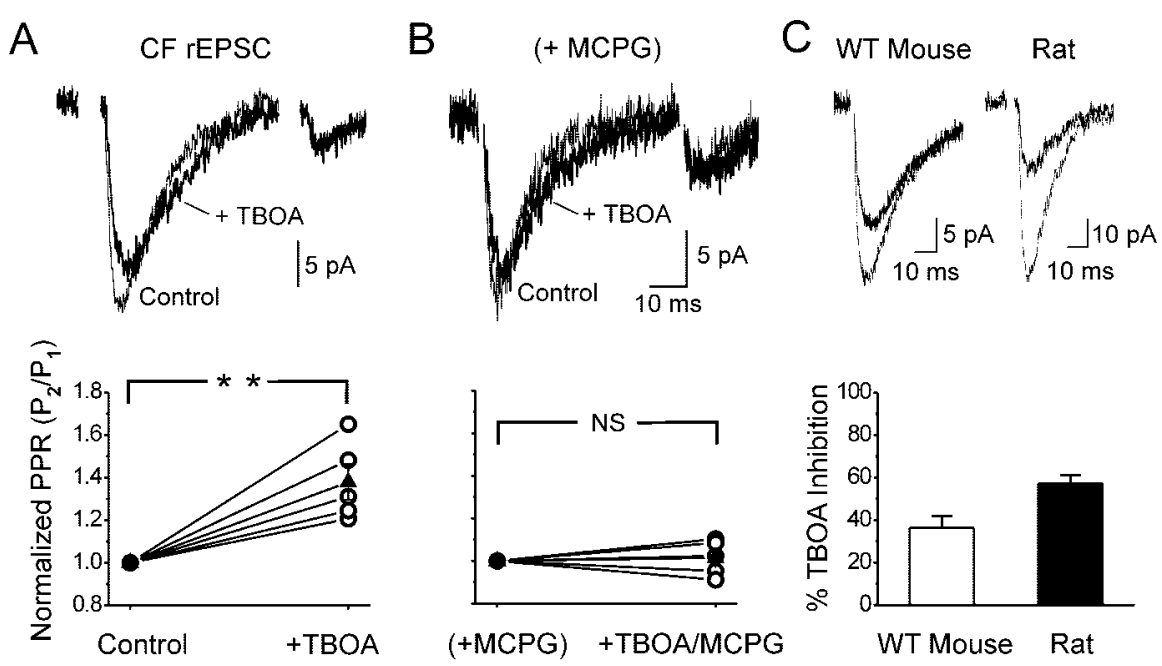

Figure 4. Measurement of the glutamate transporter component of CF rEPSCS. A, CF rEPSCs recorded from an $E A A C 1^{-1-} \times$ EAAT4 $^{-1-}$ mouse under control conditions (light traces) and in TBOA (200 $\mu \mathrm{m}$; dark traces). Below is the summary data showing that TBOA increased the PPR of these responses. $\left({ }^{* *} p<0.01\right)$. Interstimulus interval, $50 \mathrm{msec} ; \mathbf{\Delta}$, average. $B, C F$ rEPSC recorded from an $E A A C 1^{-1-} \times E A A T 4^{-1-}$ mouse under control conditions (+ $1 \mathrm{mM} \mathrm{MCPG;} \mathrm{light} \mathrm{traces)} \mathrm{and} \mathrm{in} \mathrm{the} \mathrm{presence} \mathrm{of} \mathrm{TBOA} \mathrm{(200}$ $\mu \mathrm{M})$ and MCPG (1 mM; dark traces). Below is the summary data showing that MCPG prevented the change in PPR produced by TBOA. NS, Not significant; $\mathbf{\Delta}$, average. C, CF rEPSCs recorded from a wild-type mouse (left traces) or a rat (right traces) under control conditions (light traces) and in the presence of TBOA (200 $\mu \mathrm{m})$ and MCPG (1 mm; dark traces). Below is the summary data showing the fractional contribution of transporters to the peak amplitude of the CF rEPSC. All currents were recorded in the presence of $25 \mu \mathrm{M} \mathrm{NBQX}, 25 \mu \mathrm{m}$ GYKI 52466, $10 \mu \mathrm{m}$ RS-CPP, $5 \mu \mathrm{m}$ SR-95531, and $20 \mu \mathrm{m}$ bicuculline at a holding potential of -65 $\mathrm{mV}$. The primary internal anion was MeS for all recordings. 
A

A CF rEPSC CFEPSC B
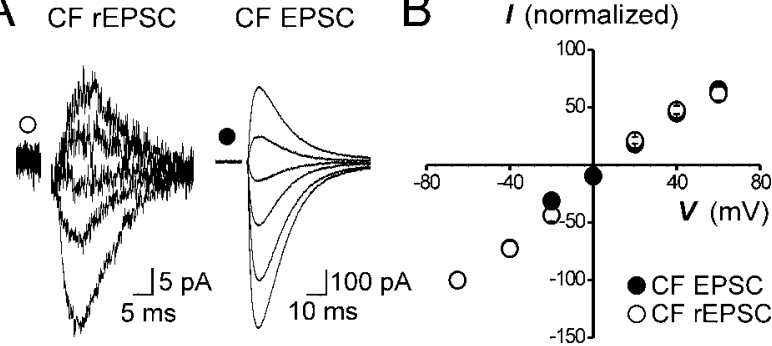

C CF r EPSC

\section{D}

CF EPSC
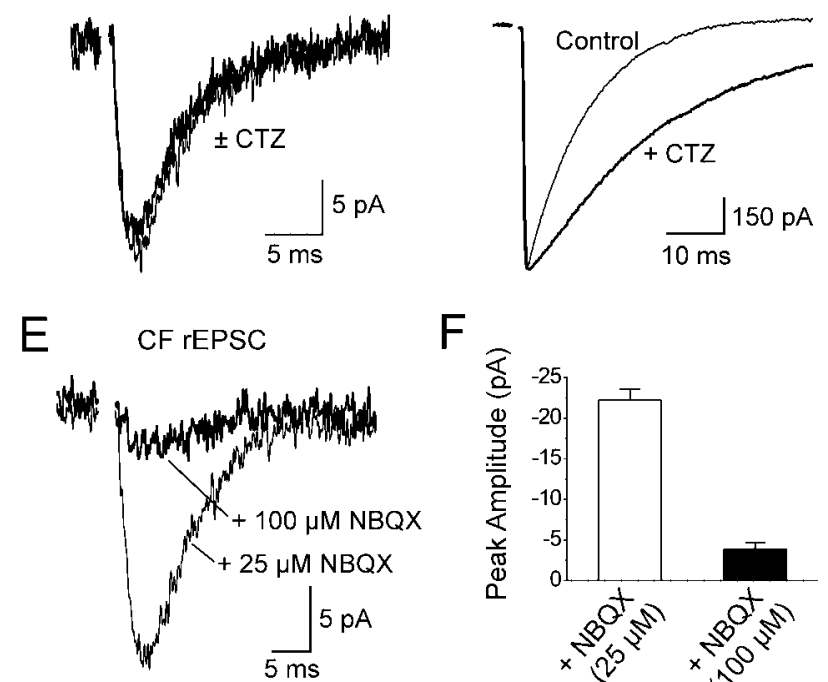

$\mathrm{F}$

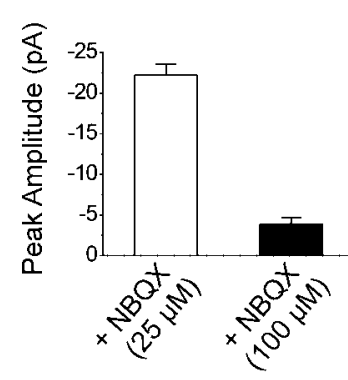

Figure 5. The CF rEPSC is mediated by non-AMPA ionotropic glutamate receptors. $A, C F$ rEPSCs (left traces) and CF EPSCs (right traces) recorded at potentials from -65 to $40 \mathrm{mV}$. $B$, Comparison of the current-voltage relationship of CF rEPSCs (O) and CF EPSCs (O). CF rEPSCs were recorded in $25 \mu \mathrm{M} \mathrm{NBQX}$, and CFEPSCs were recorded in $1 \mu \mathrm{m} \mathrm{NBQX}$ to decrease the size of the responses to prevent voltage escape at negative potentials. C, CF rEPSCS. D, CF EPSCs recorded under control conditions (light traces) and in the presence of $200 \mu \mathrm{M}$ CTZ (dark traces). The holding potential was $-65 \mathrm{mV}$ in ( and $-10 \mathrm{mV}$ in D. E, CF rEPSCs recorded under control conditions (light trace) and in the presence of $100 \mu \mathrm{m} \mathrm{NBQX} \mathrm{(dark} \mathrm{trace).} \mathrm{The} \mathrm{holding} \mathrm{potential}$ was $-65 \mathrm{mV}$. F, Summary graph showing the sensitivity of CF rEPSCs to different concentrations of NBQX. All synaptic responses were recorded from PCs in cerebellar slices from $E A A C 1^{-1-} \times E A A T 4^{-1-}$ mice. The primary anion in the internal solution was MeS for all recordings.

by examining whether the rEPSC was sensitive to cyclothiazide (CTZ), a compound that blocks AMPA receptor desensitization. As shown in Figure $5 C$, CTZ $(200 \mu \mathrm{M})$ had no effect on the amplitude or decay time of the CF rEPSC, although it caused a dramatic slowing of the CF EPSC (Fig. 5D). The CF rEPSC was insensitive to NMDA receptor antagonists (RS-CPP, $10 \mu \mathrm{M}$; MK$801,50 \mu \mathrm{M}$; 7-Cl-kynurenate, $20 \mu \mathrm{M}$; recordings made in $0 \mathrm{Mg}^{2+}$ ACSF; $5.9 \pm 1.1 \%$ inhibition; $n=3$ ), consistent with the conclusion that PCs do not express functional NMDA receptors at this age (Hausser and Roth, 1997). The insensitivity to NMDA receptor antagonists also indicates that the CF rEPSC is not mediated by an aspartate receptor (Yuzaki et al., 1996). However, the CF rEPSC was almost completely blocked by $100 \mu \mathrm{M}$ NBQX $(83.0 \pm$ $2.7 \%$ inhibition; $n=4$ ) (Fig. $5 E, F$ ), suggesting that this current is mediated by a glutamate receptor rather than a receptor for another neurotransmitter. This conclusion is supported by the observation that TBOA slowed the decay of the CF rEPSCs in $E A A C 1^{-1-} \times E A A T 4^{-1-}$ mice (decay tau: control, $8.1 \pm 0.8$ msec; TBOA, $11.1 \pm 1.6$ msec; $n=7 ; p<0.05$ ) (Fig. $4 B$ ), which

A
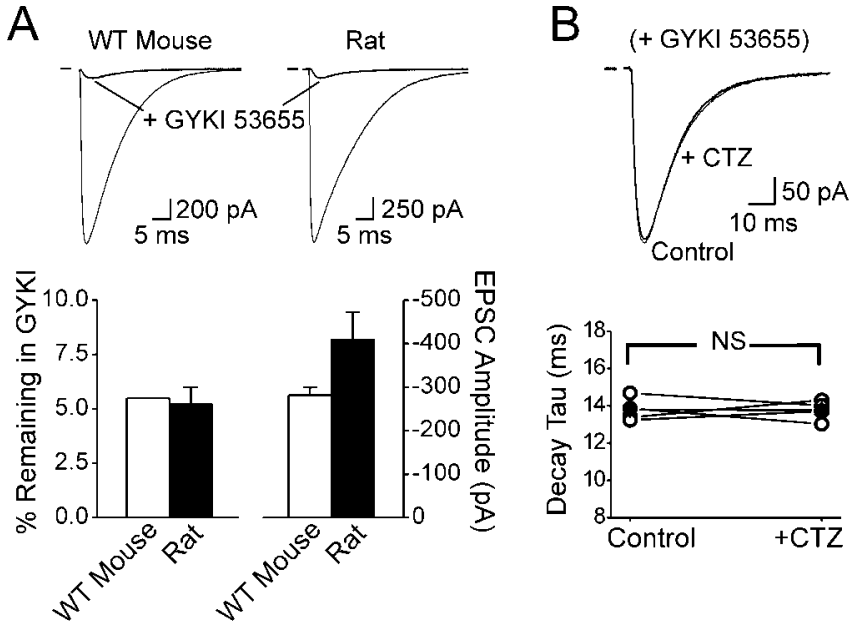

Figure 6. Size of the non-AMPA EPSC at CF-PC synapses. A, CF EPSCs recorded from a wildtype mouse (left traces) or a rat (right traces) under control conditions and in the presence of 100 $\mu \mathrm{M}$ GYKI 53655. Below is the summary data showing the percentage of contribution of the non-AMPA current to the CF EPSC and the absolute size of the non-AMPA CF synaptic current in mouse and rat. Percent inhibition was recorded at $-10 \mathrm{mV}$, and the peak current was measured at $-65 \mathrm{mV}$. B, CF EPSCs recorded in $100 \mu \mathrm{M}$ GYKI 53655 with and without $200 \mu \mathrm{M}$ CTZ. Below is the summary data showing the effect of CTZ on the decay tau of CF EPSCs recorded in $100 \mu \mathrm{m}$ GYKI 53655. These recordings were made from PCs in cerebellar slices from rat. NS, Not significant.

suggests that the ligand for these receptors is a substrate for glutamate transporters.

The sensitivity of the CF rEPSC to a higher concentration of NBQX suggested that the receptors underlying this current might have been partially blocked in $25 \mu \mathrm{M}$ NBQX. To determine the actual size of this glutamate receptor current, we measured the amplitude of the CF EPSC in GYKI $53655(100 \mu \mathrm{M})$, a selective noncompetitive AMPA receptor antagonist (Paternain et al., 1995). As shown in Figure 6A, GYKI 53655 inhibited the CF EPSC by $94.5 \pm 0.1 \%(n=2)$ in cerebellar slices from wild-type mice and by $94.8 \pm 0.8 \%(n=4)$ in cerebellar slices from rats. The CF EPSC recorded in the presence of $100 \mu \mathrm{M}$ GYKI was not contaminated by unblocked AMPA receptors, because CTZ did not affect the amplitude or time course of these residual responses (Fig. 6B). Although this non-AMPA EPSC was only a small fraction of the total CF EPSC, at $-65 \mathrm{mV}$, this current was $-281.2 \pm 18.5 \mathrm{pA}(n=3)$ in wild-type mice and $-409.4 \pm 63.6$ $\mathrm{pA}(n=7)$ in rats.

\section{Low occupancy of non-AMPA receptors at CF synapses}

CF EPSCs exhibit paired-pulse depression when two stimuli are applied at short intervals, resulting from the high release probability of CF terminals (Silver et al., 1998; Wadiche and Jahr, 2001). A striking difference in PPR was observed between CF EPSCs recorded under control conditions and responses recorded in $25 \mu \mathrm{M}$ NBQX or $100 \mu \mathrm{M}$ GYKI 53655. As shown in Figure $7 A$, the PPR of the CF EPSC was $0.73 \pm 0.01(n=6)$, whereas it was $0.33 \pm 0.03(n=6 ; p<0.001)$ for the non-AMPA CF EPSC recorded in $100 \mu \mathrm{M}$ GYKI 53655. As expected, the PPR of the non-AMPA EPSC was not significantly different from the PPR of the CF rEPSC recorded from $E A A C 1^{-1-} \times E A A T 4^{-1-}$ mice $(0.34 \pm 0.02 ; n=6 ; p=0.325)$ (Fig. $7 A)$. These differences in PPR cannot be explained by voltage clamp errors arising from the differences in the size of the AMPA and non-AMPA currents, because the PPR of the CF EPSC was unchanged when the am- 

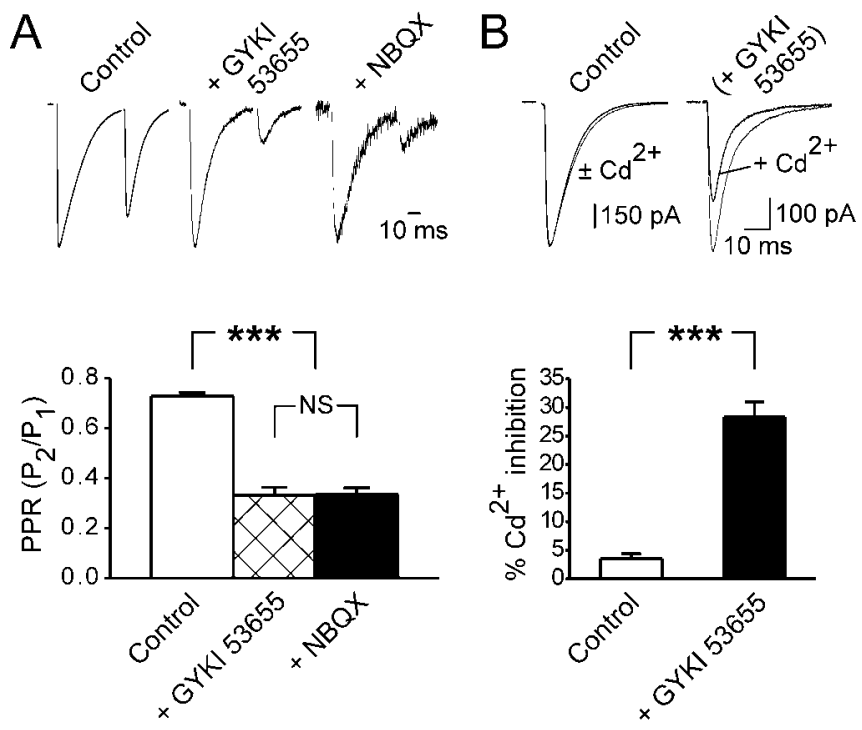

Figure 7. Non-AMPA receptors have a lower occupancy than AMPA receptors at CF-PC synapses. A, Paired-pulse responses of CF EPSCS recorded under control conditions ( $-10 \mathrm{mV}$; left traces) in the presence of $100 \mu \mathrm{m}$ GYKI 53655 ( $-10 \mathrm{mV}$; middle traces) or $25 \mu \mathrm{m} \mathrm{NBQX}$ $(-65 \mathrm{mV}$; right traces). Interstimulus interval, $50 \mathrm{msec}$. Bottom, Summary data showing that non-AMPA CF EPSCs exhibited a smaller PPR. CF EPSCs in control were recorded at $-10 \mathrm{mV}$, whereas CF EPSCs in antagonists were recorded at $-65 \mathrm{mV}$. B, CF EPSCs (left traces) and CF EPSCs in $100 \mu \mathrm{M}$ GYKI 53655 (right traces) recorded in the presence or absence of $5 \mu \mathrm{M} \mathrm{Cd}^{2+}$. Bottom, Summary data showing that non-AMPA CF EPSCs were more sensitive to extracellular $\mathrm{Cd}^{2+} .{ }^{* *} p<0.001 ; \mathrm{NS}$, not significant.

plitude of the CF EPSC was reduced by $48.1 \pm 1.0 \%$ by holding cells slightly more positive (PPR at $-10 \mathrm{mV}, 0.77 \pm 0.01$; PPR at $-2 \mathrm{mV}, 0.77 \pm 0.01 ; n=3 ; p=0.777)$. Recent results indicate that individual CF synapses may release multiple vesicles in response to a single stimulus, causing saturation of AMPA receptors (Wadiche and Jahr, 2001). This saturation of PC AMPA receptors leads to an underestimate of CF depression in pairedpulse protocols, because AMPA receptors are not able to provide an accurate measure of the first glutamate transient (Harrison and Jahr, 2003). Therefore, the greater depression of the nonAMPA EPSC suggested that these receptors might have a lower occupancy than AMPA receptors after release at CF synapses. To test this possibility, we examined the sensitivity of CF AMPA and CF non-AMPA responses (recorded in $100 \mu \mathrm{M}$ GYKI 53655) to a reduction in release probability. As shown in Figure $7 B$, partial block of presynaptic voltage-dependent $\mathrm{Ca}^{2+}$ channels with $5 \mu \mathrm{M}$ $\mathrm{Cd}^{2+}\left(\mathrm{CdCl}_{2}\right)$ caused a $28.3 \pm 2.7 \%(n=5)$ reduction in peak amplitude of the non-AMPA EPSC but only a $3.5 \pm 0.9 \%(n=4$; $p<0.001)$ decrease in the CF EPSC. This differential effect of $\mathrm{Cd}^{2+}$ on the two components of the CF EPSC is not likely to have resulted from a preferential inhibition of the non-AMPA receptors themselves, because the non-AMPA current exhibited a linear $I-V$ (Fig. $5 A$ ) characteristic of receptors that are $\mathrm{Ca}^{2+}$ impermeable. These results indicate that the non-AMPA receptors experience lower occupancy after release at CF synapses.

\section{Slow time course of non-AMPA EPSCs at CF synapses}

The rise time of the non-AMPA response (recorded in $100 \mu \mathrm{M}$ GYKI 53655) was significantly slower than that of the CF EPSC (rise time: AMPA, $0.8 \pm 0.04 \mathrm{msec}$; non-AMPA, $1.7 \pm 0.1 ; n=8$; $p<0.001$ ); however, the non-AMPA response decayed more rapidly than the AMPA current (half-decay time: AMPA, $8.7 \pm$
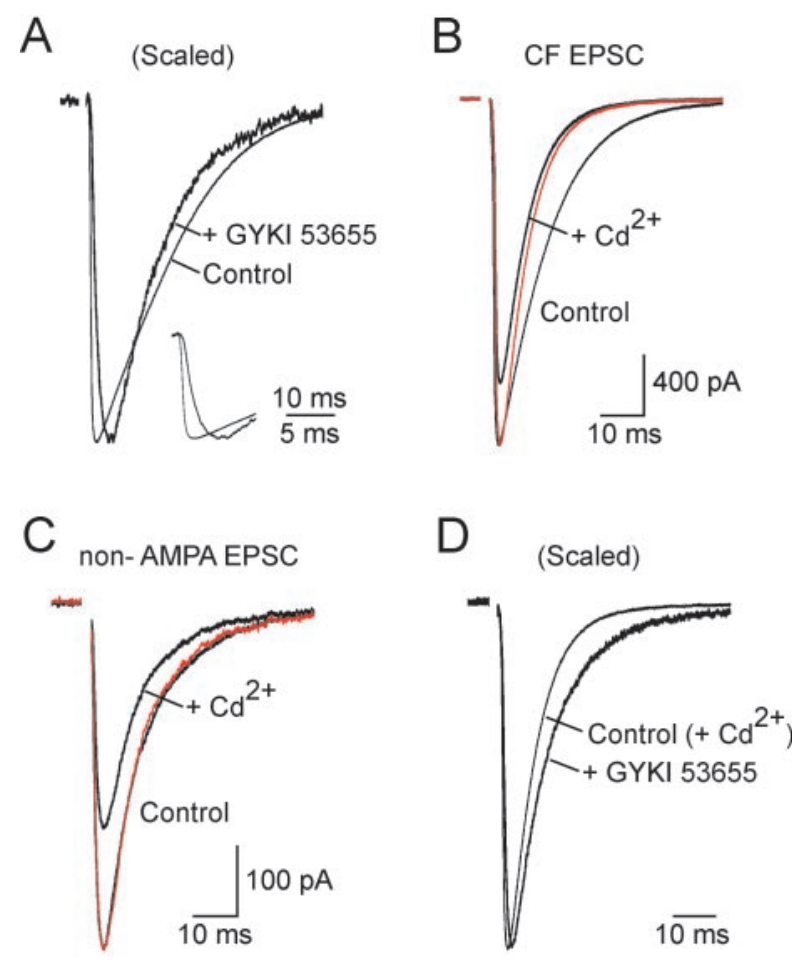

Figure 8. The non-AMPA CF synaptic current has a slow time course. A, Overlay of a CF EPSC recorded in $100 \mu \mathrm{m}$ GYKI 53655 (dark trace) scaled to the peak of the CF ESPC recorded under control conditions (light trace), illustrating the slower rise time of the non-AMPA current. Inset shows the two responses at a faster time scale. Holding potential, $-10 \mathrm{mV}$. Calibration: 10 msec (large traces), $5 \mathrm{msec}$ (inset traces). B, CF EPSCs recorded under control conditions and in the presence of $12 \mu \mathrm{M} \mathrm{Cd^{2+ }}$. The red trace is the response in $\mathrm{Cd}^{2+}$ scaled to the control response, showing the faster decay of the CF EPSC when release probability is reduced. C, CF EPSCs recorded in the presence of $100 \mu \mathrm{m}$ GYKI $53655 \pm 5 \mu \mathrm{m} \mathrm{Cd}^{2}$. The red trace is the response in $\mathrm{Cd}^{2+}$ scaled to the control response, showing that the reduction in release probability did not alter the decay of the non-AMPA EPSC. D, Overlay of a CF EPSC recorded in $12 \mu \mathrm{m} \mathrm{Cd}{ }^{2+}$ (light trace) and in $100 \mu \mathrm{m}$ GYKI 53655 (dark trace). The response in GYKI has been scaled to the peak of the CF response in $12 \mu \mathrm{m} \mathrm{Cd}{ }^{2+}$. Holding potential: $-10 \mathrm{mV}$ for the CFEPSC; $-65 \mathrm{mV}$ for the response in GYKI.

0.6 msec; non-AMPA, $5.9 \pm 0.3 ; n=8 ; p<0.001$ ) (Fig. $8 A$ ). The decay of the CF AMPA current may be prolonged because of saturation of AMPA receptors and slow clearance of glutamate (Barbour et al., 1994), which allows repeated binding to receptors and perhaps spillover onto nearby receptor clusters (Wadiche and Jahr, 2001). To address whether the slower decay of the CF AMPA response is a consequence of AMPA receptor saturation, we examined the decay of these two components under reduced release conditions. Because the AMPA response in $5 \mu \mathrm{M} \mathrm{Cd}^{2+}$ was still close to saturation (Fig. $7 B$ ), we raised the $\mathrm{Cd}^{2+}$ concentration to $12 \mu \mathrm{M}$. This reduced the peak amplitude of the AMPA response by $20.4 \pm 1.8 \%(n=3)$ and the decay time to $4.7 \pm 0.4$ msec (half-decay; decay tau, $5.4 \pm 0.4 \mathrm{msec} ; n=3 ; p<0.01$ ) (Fig. $8 B)$, similar to results shown by Wadiche and Jahr (2001). In contrast, application of $5 \mu \mathrm{M} \mathrm{Cd}^{2+}$ did not alter the decay of the non-AMPA response (decay tau: control, $10.1 \pm 0.4 \mathrm{msec}$; $\left.+\mathrm{Cd}^{2+}, 9.6 \pm 0.5 \mathrm{msec} ; n=8 ; p=0.101\right)($ Fig. $8 C)$. In Figure $8 D$, the non-AMPA response recorded in $100 \mu \mathrm{M}$ GYKI 53655 is scaled to the peak amplitude of the AMPA response recorded under lowered release conditions $\left(12 \mu \mathrm{M} \mathrm{Cd}^{2+}\right)$, illustrating the significantly slower rise and decay of the non-AMPA response $(p<0.001)$. 
A
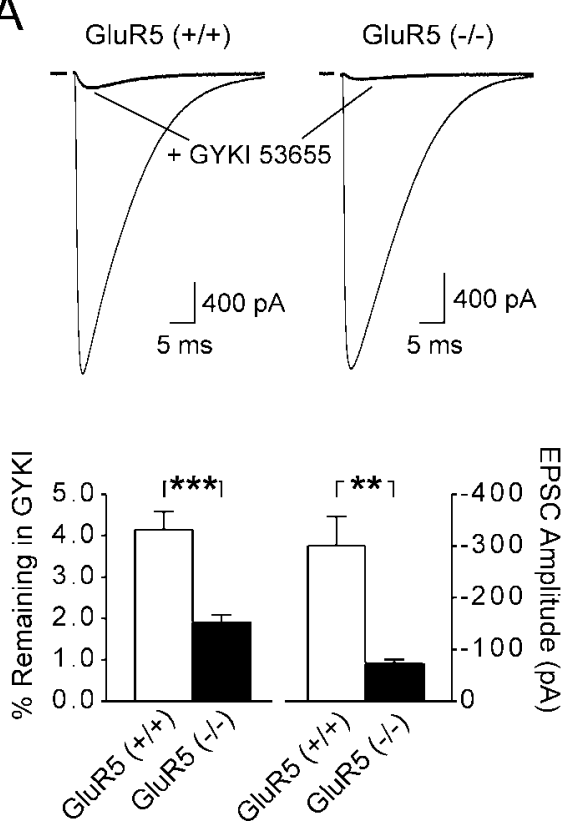

Figure 9. Kainate receptors are responsible for the non-AMPA CF EPSC. A, CF EPSCS recorded from GluR5 ${ }^{-1-}$ mice (right traces) and wild-type littermates (left traces) under control conditions and in the presence of $100 \mu \mathrm{M}$ GYKI 53655. Holding potential, $-10 \mathrm{mV}$. The graph below shows the percentage of contribution of the non-AMPA current to the CF EPSC and the peak amplitude of the current remaining in GYKI 53655 (recorded at $-65 \mathrm{mV}$ ) in these two groups of animals. $B$, CF EPSCs recorded in $100 \mu \mathrm{M}$ GYKI 53655 from wild-type (left traces) and GluR5 ${ }^{-1-}$ mice (right traces) showing the amount of inhibition by the kainate receptor antagonist LY $382884(10 \mu \mathrm{M})$. Holding potential, $-65 \mathrm{mV}$. Below is the summary data showing the sensitivity of the non-AMPA EPSC to $10 \mu \mathrm{m} L \mathrm{Y} 382884$ in these two groups of animals.

\section{Kainate receptors are responsible for the non-AMPA EPSC}

Fast excitatory transmission is mediated by three classes of ionotropic glutamate receptors, AMPA, NMDA, and kainate receptors. At synapses where both AMPA and kainate receptors are expressed, kainate receptor-mediated currents exhibit a smaller amplitude and slower kinetics (Lerma, 2003), similar to the nonAMPA receptor currents recorded at CF synapses. PCs express both GluR5 and KA1 kainate receptors (Wisden and Seeburg, 1993), and functional kainate receptors are expressed by these cells (Brickley et al., 1999). To address the possible contribution of GluR5 receptors to the CF EPSC, we recorded CF responses from PCs in slices prepared from GluR $5^{-1-}$ mice (Contractor et al., 2000). If GluR5-containing kainate receptors contribute to the non-AMPA response, GYKI 53655 should inhibit a greater fraction of the CF EPSC in animals lacking this subunit. As shown in Figure 9A, application of $100 \mu \mathrm{M}$ GYKI 53655 inhibited CF EPSCs by $98.1 \pm 0.2 \%(n=9)$ in GluR $5^{-1-}$ mice compared with $95.9 \pm 0.4 \%(n=9 ; p<0.001)$ in wild-type littermates, and the amplitude of the residual current was dramatically reduced in GluR5 ${ }^{-1-}$ mice (peak current in GYKI at $-65 \mathrm{mV}$ : GluR5 ${ }^{-/-}$, $-71.9 \pm 8.3 \mathrm{pA}, n=12$; wild-type, $-300.6 \pm 56.1 \mathrm{pA}, n=9 ; p<$ 0.01 ). In addition, CF non-AMPA responses (recorded in $100 \mu \mathrm{M}$ GYKI 53655) from wild-type mice were inhibited by $70.3 \pm 0.4 \%$ $(n=5)$ by LY $382884(10 \mu \mathrm{M})($ rats, $78.0 \pm 0.2 \% ; n=4)$ (Fig. $9 B$ ), an antagonist that exhibits an $\sim 100$-fold greater selectivity for kainate receptors over AMPA receptors (Bortolotto et al., 1999; Lerma et al., 2001). In GluR5 ${ }^{-1-}$ mice, these responses were only inhibited by $15.7 \pm 1.8 \%(n=5 ; p<0.001)$ by $10 \mu \mathrm{M}$ LY 382884. The inhibition seen in wild-type mice is unlikely to have resulted from presynaptic actions of this compound, because the PPR of the CF non-AMPA response was unchanged in the presence of LY $382884(10 \mu \mathrm{M})\left(\mathrm{PPR}_{\text {control }}, 0.31 \pm 0.01\right.$;
$\left.\mathrm{PPR}_{\mathrm{LY}}, 0.32 \pm 0.01 ; n=5 ; p=0.150\right)$. These data indicate that the CF EPSC is generated by two distinct glutamate receptors, AMPA receptors and kainate receptors, and that GluR5-containing kainate receptors are responsible for the majority of the non-AMPA EPSC at CF synapses.

\section{Discussion}

In this study, we analyzed CF synaptic currents from mice deficient in EAAC1 and EAAT4 and found that both stoichiometric and anion transporter currents were absent in mice lacking EAAT4 but not EAAC1, suggesting that EAAT4 has a specialized role in clearing glutamate released at CF synapses. The inability to detect synaptic currents mediated by EAAC1 suggests that this transporter is present at a much lower density than EAAT4 near CF synapses. These data are in accordance with the hypothesis that EAAC1 is primarily a metabolic transporter (Rothstein et al., 1996; Sepkuty et al., 2002), rather than one involved in clearing synaptic glutamate. However, because EAAT4 is primarily restricted to PCs in the mature brain, EAAC1 may perform a similar role at some excitatory synapses (He et al., 2000; Diamond, 2001), perhaps at synapses that are partially ensheathed by glia (Ventura and Harris, 1999).

CF synaptic currents recorded in $25 \mu \mathrm{M}$ NBQX were believed to reflect the activity of glutamate transporters exclusively, with the amount of charge transferred during these responses proportional to the amount of glutamate taken up into PCs. Estimates based on transporter-associated anion currents suggested that $\geq 22 \%$ of the glutamate released at CF synapses is taken up by PCs (Otis et al., 1997), whereas measurements based on stoichiometric transporter currents suggested that the majority of this glutamate (56-230\%) is removed by PCs (Auger and Attwell, 2000). The latter estimate is surprising given the tight ensheathment of PC synapses by Bergmann glial cells (Spacek, 1985) and the higher density of transporters in these membranes (Lehre et al., 1995). However, because kainate receptors contribute to the synaptic currents recorded in $25 \mu \mathrm{M}$ NBQX (see below), the amount of glutamate removed by PCs has been overestimated. Unfortunately, merely subtracting the rEPSC in TBOA from control will not provide an accurate measure of the charge transferred by glutamate transporters, because TBOA altered the activation of the receptors contributing to the rEPSC (Fig. 4). If the transporter kinetics are similar to the rEPSC, our results indicate that glutamate transporters transfer $43 \%$ less charge than previously estimated (Auger and Attwell, 2000). The error is less (25\%) for estimates based on rEPSCs recorded with $\mathrm{NO}_{3}{ }^{-}$as the primary internal anion (Otis et al., 1997), because transporters contribute proportionally more to the rEPSC when permeant anions are present in the internal solution (Fig. 2). However, both estimates were based on the assumption that each CF synapse releases only a single vesicle during stimulation, whereas recent results indicate that multivesicular release predominates at CF synapses (Wadiche and Jahr, 2001). Assuming that CFs release on average three vesicles per site, then $<10 \%$ of the glutamate released by the $\mathrm{CF}$ is 
removed by EAAT4; the majority is presumably taken up by Bergmann glial cells (Bergles et al., 1997). This division of labor suggests that glial transporters may play a dominant role in restricting the activation of perisynaptic metabotropic glutamate receptors at CF synapses (Dzubay and Otis, 2002).

EAAT4 reaches a density of $3600 \mu \mathrm{m}^{2}$ in the peridendritic membrane (Dehnes et al., 1998), whereas the transporter density in Bergmann glial membranes is $5400 \mu \mathrm{m}^{2}$ (Lehre and Danbolt, 1998). If half of the glutamate diffuses in the postsynaptic direction after release (ignoring possible biased diffusion because of the larger number of postsynaptic transporters), and transporters in this region capture all of this glutamate, EAAT4 should remove $\sim 20 \%$ of the glutamate released at CF synapses. The lower uptake observed may indicate that a significant fraction of glutamate escapes transporters in this region, fewer EAAT4 transporters (or more glial transporters) are available to bind glutamate, or EAAT4 transporters are saturated. Note that immunolocalization studies indicate that EAAT4 expression varies by a factor of three among PCs (Dehnes et al., 1998), with highest expression observed in zebrin (aldolase C)-immunoreactive bands. The physiological significance of this expression pattern is not known, but these data suggest that the postsynaptic contribution to uptake may vary considerably among CF synapses. It is possible that EAAT4 may capture more glutamate at physiological temperatures, because binding would be expected to increase more than diffusion. Although the EAAT4-associated charge transfer was not increased at near physiological temperatures, the PPR of the CF EPSC (recorded in GYKI 53655) increased by $~ 28 \%$ at this temperature, raising the possibility that release probability is lower at higher temperatures and that EAAT4 captures a greater percentage of the glutamate released.

\section{Kainate receptors contribute to the excitation of PCs}

A CF synaptic current remained in $E A A C 1^{-1-} \times E A A T 4^{-1-}$ mice in the presence of $25 \mu \mathrm{M}$ NBQX, which reversed at the same potential as the CF EPSC and was not blocked by TBOA, indicating that it was not mediated by glutamate transporters. Given the large amount of glutamate released at CF synapses (Wadiche and Jahr, 2001) and the slow clearance of this glutamate away from PC AMPA receptors (Barbour et al., 1994), there is concern that a competitive antagonist such as NBQX could be displaced; although, neither the amplitude nor the decay time of rEPSCs was affected by CTZ $(200 \mu \mathrm{M})$, as would be expected if this current was mediated by unblocked AMPA receptors (Rammes et al., 1998). However, this residual current was largely blocked by a higher dose of NBQX (100 $\mu \mathrm{M})$, suggesting that it is mediated by non-NMDA glutamate receptors. By measuring the size of the CF EPSC remaining in the noncompetitive AMPA receptor antagonist GYKI $53655(100 \mu \mathrm{M})$, we determined that these receptors mediate $~ 5 \%$ of the CF EPSC; although a minor component, this current was approximately $-250 \mathrm{pA}$ (mice) to $-400 \mathrm{pA}$ (rats) at the resting potential.

Glutamate receptor currents that are insensitive to GYKI 53655 and blocked by NBQX are thought to be mediated by kainate receptors (Lerma, 2003). Both GluR5 and KA1 kainate receptor subunits are expressed by PCs (Wisden and Seeburg, 1993), and the selective kainate receptor agonist domoate elicits currents in PCs (in GYKI 53655) (Brickley et al., 1999), indicating that functional kainate receptors are formed. A previous study (Brickley et al., 1999) reported that CF EPSCs in PCs from wildtype mice were completely blocked by $100 \mu \mathrm{M}$ GYKI 53655, concluding that kainate receptors were restricted to extrasynaptic sites. However, we show here that the portion of CF EPSC, which was insensitive to GYKI 53655, was inhibited by the kainate receptor antagonist LY 382884 at a concentration that does not affect AMPA receptors (Bortolotto et al., 1999). In GluR5 ${ }^{-1-}$ mice, the size of this GYKI-insensitive current was much smaller, and this residual current was largely insensitive to LY 382884. These data suggest that GluR5-containing kainate receptors are responsible for the majority of the GYKI-insensitive CF response. The cause of the discrepancy between our data and that of Brickley et al. (1999) is not known; however, small currents at the $\mathrm{CF}-\mathrm{PC}$ synapses can be obscured by stimulation artifacts (Auger and Attwell, 2000).

At synapses that express both AMPA and kainate receptors, kainate receptor synaptic currents are typically $\sim 10 \%$ as large as those mediated by AMPA receptors and exhibit slower rise and decay kinetics (Lerma, 2003). Consistent with these observations, the CF kainate receptor EPSC was much smaller than the AMPA receptor current and had a much slower rise and decay time (under reduced release conditions) (Fig. 8D). The decay time of these currents was $\sim 10 \mathrm{msec}$ (decay tau), remarkably similar to the decay of kainate receptor synaptic currents recorded from hippocampal interneurons (Cossart et al., 2002) and for heterologously expressed kainate receptors (Swanson and Heinemann, 1998). Perhaps related to their slower kinetics, kainate receptors appear to be further from saturation than AMPA receptors (Bureau et al., 2000; Kidd and Isaac, 2001). CF EPSCs recorded in GYKI 53655 (or NBQX) exhibited a much smaller PPR than CF EPSCs recorded under control conditions and were more sensitive to a reduction in release probability (Fig. $7 B$ ). These results suggest that despite the large amount of glutamate released from CFs, PC kainate receptors experience a lower occupancy than AMPA receptors. The small effect of transporter inhibition on CF rEPSCs suggests that this may result from their lower affinity rather than a location remote from release sites (Bureau et al., 2000; Kidd and Isaac, 2001).

Although much smaller in amplitude than AMPA receptor currents, the slower time course of kainate receptor responses allows greater temporal summation of synaptic inputs (Frerking and Ohliger-Frerking, 2002). It is unlikely that kainate receptors perform a similar function at CF synapses, because under physiological release conditions, the decay of the kainate receptor current was faster than the AMPA receptor current. The small amplitude of the kainate response suggests that these receptors are also not essential for complex spike generation. Although the functional significance of these PC kainate receptors remains to be determined, recent results suggest that kainate receptors may also function as metabotropic receptors (Rozas et al., 2003), raising the possibility that these receptors may regulate the efficacy of other inputs onto PCs.

\section{References}

Arnth-Jensen N, Jabaudon D, Scanziani M (2002) Cooperation between independent hippocampal synapses is controlled by glutamate uptake. Nat Neurosci 5:325-331.

Auger C, Attwell D (2000) Fast removal of synaptic glutamate by postsynaptic transporters. Neuron 28:547-558.

Barbour B, Keller BU, Llano I, Marty A (1994) Prolonged presence of glutamate during excitatory synaptic transmission to cerebellar Purkinje cells. Neuron 12:1331-1343.

Bergles DE, Dzubay JA, Jahr CE (1997) Glutamate transporter currents in bergmann glial cells follow the time course of extrasynaptic glutamate. Proc Natl Acad Sci USA 94:14821-14825.

Bergles DE, Tzingounis AV, Jahr CE (2002) Comparison of coupled and uncoupled currents during glutamate uptake by GLT-1 transporters. J Neurosci 22:10153-10162.

Bortolotto ZA, Clarke VR, Delany CM, Parry MC, Smolders I, Vignes M, Ho 
KH, Miu P, Brinton BT, Fantaske R, Ogden A, Gates M, Ornstein PL, Lodge D, Bleakman D, Collingridge GL (1999) Kainate receptors are involved in synaptic plasticity. Nature 402:297-301.

Brasnjo G, Otis TS (2001) Neuronal glutamate transporters control activation of postsynaptic metabotropic glutamate receptors and influence cerebellar long-term depression. Neuron 31:607-616.

Brickley S, Swanson G, Contractor A, Farrant M, Sailer A, Cull-Candy S, Heinemann S (1999) Functional GluR5-containing kainate receptors are restricted to extrasynaptic sties in Purkinje cells of the mouse cerebellum. J Physiol (Lond) 521:90P.

Bureau I, Dieudonne S, Coussen F, Mulle C (2000) Kainate receptormediated synaptic currents in cerebellar Golgi cells are not shaped by diffusion of glutamate. Proc Natl Acad Sci USA 97:6838-6843.

Contractor A, Swanson GT, Sailer A, O’Gorman S, Heinemann SF (2000) Identification of the kainate receptor subunits underlying modulation of excitatory synaptic transmission in the CA3 region of the hippocampus. J Neurosci 20:8269-8278.

Cossart R, Epsztein J, Tyzio R, Becq H, Hirsch J, Ben-Ari Y, Crepel V (2002) Quantal release of glutamate generates pure kainate and mixed AMPA/ kainate EPSCs in hippocampal neurons. Neuron 35:147-159.

Danbolt NC (2001) Glutamate uptake. Prog Neurobiol 65:1-105.

Dehnes Y, Chaudhry FA, Ullensvang K, Lehre KP, Storm-Mathisen J, Danbolt NC (1998) The glutamate transporter EAAT4 in rat cerebellar Purkinje cells: a glutamate-gated chloride channel concentrated near the synapse in parts of the dendritic membrane facing astroglia. J Neurosci 18:3606-3619.

Diamond JS (2001) Neuronal glutamate transporters limit activation of NMDA receptors by neurotransmitter spillover on CA1 pyramidal cells. J Neurosci 21:8328-8338.

Diamond JS, Jahr CE (1997) Transporters buffer synaptically released glutamate on a submillisecond time scale. J Neurosci 17:4672-4687.

Dzubay JA, Otis TS (2002) Climbing fiber activation of metabotropic glutamate receptors on cerebellar purkinje neurons. Neuron 36:1159-1167.

Fairman WA, Vandenberg RJ, Arriza JL, Kavanaugh MP, Amara SG (1995) An excitatory amino-acid transporter with properties of a ligand-gated chloride channel. Nature 375:599-603.

Frerking M, Ohliger-Frerking P (2002) AMPA receptors and kainate receptors encode different features of afferent activity. J Neurosci 22:7434-7443.

Harrison J, Jahr CE (2003) Receptor occupancy limits synaptic depression at climbing fiber synapses. J Neurosci 23:377-383.

Hausser M, Roth A (1997) Dendritic and somatic glutamate receptor channels in rat cerebellar Purkinje cells. J Physiol (Lond) 501:77-95.

He Y, Janssen WG, Rothstein JD, Morrison JH (2000) Differential synaptic localization of the glutamate transporter EAAC1 and glutamate receptor subunit GluR2 in the rat hippocampus. J Comp Neurol 418:255-269.

Jabaudon D, Shimamoto K, Yasuda-Kamatani Y, Scanziani M, Gahwiler BH, Gerber U (1999) Inhibition of uptake unmasks rapid extracellular turnover of glutamate of nonvesicular origin. Proc Natl Acad Sci USA 96:8733-8738.

Kidd FL, Isaac JT (2001) Kinetics and activation of postsynaptic kainate receptors at thalamocortical synapses: role of glutamate clearance. J Neurophysiol 86:1139-1148.

Lehre KP, Danbolt NC (1998) The number of glutamate transporter subtype molecules at glutamatergic synapses: chemical and stereological quantification in young adult rat brain. J Neurosci 18:8751-8757.

Lehre KP, Levy LM, Ottersen OP, Storm-Mathisen J, Danbolt NC (1995) Differential expression of two glial glutamate transporters in the rat brain: quantitative and immunocytochemical observations. J Neurosci 15:1835-1853.

Lerma J (2003) Roles and rules of kainate receptors in synaptic transmission. Nat Rev Neurosci 4:481-495.

Lerma J, Paternain AV, Rodriguez-Moreno A, Lopez-Garcia JC (2001) Molecular physiology of kainate receptors. Physiol Rev 81:971-998.

Otis TS, Wu YC, Trussell LO (1996) Delayed clearance of transmitter and the role of glutamate transporters at synapses with multiple release sites. J Neurosci 16:1634-1644.
Otis TS, Kavanaugh MP, Jahr CE (1997) Postsynaptic glutamate transport at the climbing fiber-Purkinje cell synapse. Science 277:1515-1518.

Paternain AV, Morales M, Lerma J (1995) Selective antagonism of AMPA receptors unmasks kainate receptor-mediated responses in hippocampal neurons. Neuron 14:185-189.

Peghini P, Janzen J, Stoffel W (1997) Glutamate transporter EAAC-1deficient mice develop dicarboxylic aminoaciduria and behavioral abnormalities but no neurodegeneration. EMBO J 16:3822-3832.

Perkel DJ, Hestrin S, Sah P, Nicoll RA (1990) Excitatory synaptic currents in Purkinje cells. Proc R Soc Lond B Biol Sci 241:116-121.

Rammes G, Swandulla D, Spielmanns P, Parsons CG (1998) Interactions of GYKI 52466 and NBQX with cyclothiazide at AMPA receptors: experiments with outside-out patches and EPSCs in hippocampal neurones. Neuropharmacology 37:1299-1320.

Rothstein JD, Martin L, Levey AI, Dykes-Hoberg M, Jin L, Wu D, Nash N, Kuncl RW (1994) Localization of neuronal and glial glutamate transporters. Neuron 13:713-725.

Rothstein JD, Dykes-Hoberg M, Pardo CA, Bristol LA, Jin L, Kuncl RW, Kanai Y, Hediger MA, Wang Y, Schielke JP, Welty DF (1996) Knockout of glutamate transporters reveals a major role for astroglial transport in excitotoxicity and clearance of glutamate. Neuron 16:675-686.

Rozas JL, Paternain AV, Lerma J (2003) Noncanonical signaling by ionotropic kainate receptors. Neuron 39:543-553.

Sepkuty JP, Cohen AS, Eccles C, Rafiq A, Behar K, Ganel R, Coulter DA, Rothstein JD (2002) A neuronal glutamate transporter contributes to neurotransmitter GABA synthesis and epilepsy 22:6372-6379.

Shigeri Y, Shimamoto K, Yasuda-Kamatani Y, Seal RP, Yumoto N, Nakajima T, Amara SG (2001) Effects of threo-beta-hydroxyaspartate derivatives on excitatory amino acid transporters (EAAT4 and EAAT5). J Neurochem 79:297-302.

Shimamoto K, Lebrun B, Yasuda-Kamatani Y, Sakaitani M, Shigeri Y, Yumoto N, Nakajima T (1998) DL-threo-beta-benzyloxyaspartate, a potent blocker of excitatory amino acid transporters. Mol Pharmacol 53:195-201.

Shimamoto K, Shigeri Y, Yasuda-Kamatani Y, Lebrun B, Yumoto N, Nakajima T (2000) Syntheses of optically pure beta-hydroxyaspartate derivatives as glutamate transporter blockers. Bioorg Med Chem Lett 10:2407-2410.

Silver RA, Momiyama A, Cull-Candy SG (1998) Locus of frequencydependent depression identified with multiple-probability fluctuation analysis at rat climbing fibre-Purkinje cell synapses. J Physiol (Lond) 510:881-902.

Spacek J (1985) Three-dimensional analysis of dendritic spines. III. Glial sheath. Anat Embryol (Berl) 171:245-252.

Swanson GT, Heinemann SF (1998) Heterogeneity of homomeric GluR5 kainate receptor desensitization expressed in HEK293 cells. J Physiol (Lond) 513:639-646.

Tamaru Y, Nomura S, Mizuno N, Shigemoto R (2001) Distribution of metabotropic glutamate receptor mGluR3 in the mouse CNS: differential location relative to pre- and postsynaptic sites. Neuroscience 106:481-503.

Tanaka K, Watase K, Manabe T, Yamada K, Watanabe M, Takahashi K, Iwama H, Nishikawa T, Ichihara N, Hori S, Takimoto M, Wada K (1997) Epilepsy and exacerbation of brain injury in mice lacking the glutamate transporter GLT-1 276:1699-1702.

Tong G, Jahr CE (1994) Block of glutamate transporters potentiates postsynaptic excitation. Neuron 13:1195-1203.

Ventura R, Harris KM (1999) Three-dimensional relationships between hippocampal synapses and astrocytes. J Neurosci 19:6897-6906.

Wadiche JI, Jahr CE (2001) Multivesicular release at climbing fiberPurkinje cell synapses. Neuron 32:301-313.

Wadiche JI, Amara SG, Kavanaugh MP (1995) Ion fluxes associated with excitatory amino acid transport. Neuron 15:721-728.

Wisden W, Seeburg PH (1993) A complex mosaic of high-affinity kainate receptors in rat brain. J Neurosci 13:3582-3598.

Yuzaki M, Forrest D, Curran T, Connor JA (1996) Selective activation of calcium permeability by aspartate in Purkinje cells. Science 273:11121114. 